\title{
AZ ALFÖLD FÖLDHASZNOSÍTÁSI SZERKEZETÉNEK VÁRHATÓ ÁTALAKULÁSA
}

\author{
(Expected Situation of he Structure of Land Use of the \\ Great Hungarian Plain)
}

BERÉNYI ISTVÁN

\section{Bevezetés}

A magyar mezõgazdaság 1965-1985 között a KGST-n belül hasonló szerepet játszott, mint száz évvel korábban a Monarchia piacán. Következésképpen a mesterségesen fenntartott szocialisztikus piaci mechanizmus eltủnése, elsố lépésben a partnerországok fizetésképtelensége, majd a politikai keret szétesése a hazai agrártermelést súlyos válságba sodorta. Nyilvánvalóvá vált, hogy a költségekre alig érzékeny nagyüzemi termelési struktúra is tarthatatlan, hiszen a 80-as évek közepén a termelôszövetkezeteknek már több mint $40 \%$-a nem tudta elõállítani az újratermelés feltételeit (Enyedi Gy.-né - Kovács Cs. 1989).

Az agrárpiac alakulására a belsố gazdasági folyamatok is kedvezốtlenül hatottak (a fogyasztás visszaesése), de az agrárexport nyugati orientációja sem jelentett mentőövet az EK-piac viszonylagos zártsága, sajátos igénye és korlátozott felvevốképessége miatt. A fentiekbốl következik, hogy az ország mezógazdaságilag hasznosított területe, különösen a szántó nagysága ,túlméretezett”, tehát a kevésbé termékeny területek hasznosítása egyre gazdaságtalanabb. Az átlagosan 3000 hektáros üzemméret sem tartható, hiszen ez esetben a termốterület több mint $70 \%$-a szántó.

Az 1980-as évek elejére a nagyüzemi földhasználatnak más negatívumai is felszínre kerültek, többek között a környezet általános leromlása, a talajok termôképességének gyors csökkenése, a talajvíz elszennyezôdése, a hulladékelhelyezés megoldatlansága, a nagyüzemi telepek infrastruktúrájának elhanyagoltsága stb. Valójában a hazai agrárterület tényleges ökológiai állapotáról, illetve annak regionális különbségeirổl nincs olyan átfogó, ugyanakkor kellóen megalapozott ismeretünk, amely alkalmas lehetne a földhasznosítási szerkezet átalakítási irányainak kijelölésére. Az idõ sürget, mert félố, hogy a mezõgazdasági vállalkozók és kisbefektetổk olyan mũvelési módokba, termelési ágakba invesztálnak, amelyek a közös piaci rendszerben életképtelenek lesznek. Az esetleges EK-csatlakozás ugyanis nemcsak az ipart, hanem a mezõgazdaságot is ,,szelektív' fejlesztésre kényszeríti. 
Berényi István : Az Alföld földhasznositási szerkezetének várható átalakulása

(Expected Situation of he Structure of Land Use of the Great Hungarian Plain)

Tér és Társadalom 7. évf. 1993/3-4. 67-76. p.

Egymást érik a falusi térségek jövôjérốl, $s$ így az agrártermelés új európai lehetôségeirốl szóló konferenciák (pl. Düsseldorf, 1993. december 2-3.), ahol az előadók sürgetik az európai agrárpolitika alapvetố újragondolását. Henrichsmeyer (1994) szerint az a tény, hogy az EK éves költségvetésének $65 \%$-át az agrártámogatás viszi el, tarthatatlan. A megkezdett agrárreform következménye lesz az agrártermékek felvásárlási árának $30-40 \%$-os csökkenése, aminek várható hatása a mezõgazdasági terület további $15 \%$-os zsugorodása. A szerzõ megítélése szerint ez azzal jár, hogy a természetvédelmi jellegũ területek kiterjedése növekszik, a föld és a földbérlet árának csökkenésével pedig felértékelổnek a relatíve gyengébb adottságú területek, amelyek Európa agrárterületének 30-40\%-át teszik ki. Mindez összességében az agrártermelés külterjesedésének irányába hat, ami felerốsíti az ökológiai adottságokhoz való racionálisabb alkalmazkodást.

Henrichsmeyer fenti jövôképében azok a problémák, illetve megoldásuknak azon lehetốségei villannak fel, amelyek az európai agrártermelésben évtizedek óta jelen vannak, de amelyeket az 1989 utáni fordulat élezett ki igazán. Különösen azzal, hogy a volt szocialista országok az EK-tagságra apellálnak. Hazai szempontból persze szolid optimizmussal is tekinthetnénk az áhított ,,egységes" európai piac felé, hiszen agrárterületünk több mint fele a kontinens legjobb termôképességû területei közé tartozik, elméletileg ,,versenyképes". Kérdés, mikor jutnak e komparatív elônyök érvényre, $s$ addig ,,miből él meg" a hazai agrárvidék. Ez elsősorban az Alföld dilemmája, hiszen az iparszerkezet is részben az agrártermelés függvénye.

Megítélésem szerint a hazai földhasználat szerkezet-átalakulása során groteszk jelenségekkel kell számolni az elkövetkezó években, mert azt nem a termelés piaci átalakulása formálja csupán, hanem olyan ellentétek is, mint a vergôdô nagyüzem-maradványok és az átmenetileg életre kapott kisüzemek közöttiek, amelyekből csak lassan kerülnek ki az életképes mezőgazdasági vállalkozók. Továbbá az intenzív és extenzív hasznositás jelenléte azonos termőhelyi adottságú körzetekben, a lokális piac köré szervezôdố termelés és a felvásárlói rendszer szövevényes továbbélése stb.

Hazánk - s így az Alföld - földhasználatának átalakulását tehát egy külsõ, fốként piaci és egy belsố, fốként regionális fejlôdési lehetổség fogja orientálni. E tanulmányban az utóbbi lehetôségre kívánok rávilágítani.

\section{A természeti eröforrások térszerkezete és a földhasználat összefüggése}

Az 1980-as évek elején az ásványi nyersanyagok előfordulása, a talajminőség és a vízkészlet alapján készítettünk áttekintõ térképet az ország ,,természeti erőforrás térszerkezetérốl". A módszerrốl annyit, hogy:

- elsỗ lépésben felmértük a három erôforrás településszintũ előfordulását; 
Berényi István : Az Alföld földhasznosítási szerkezetének várható átalakulása

(Expected Situation of he Structure of Land Use of the Great Hungarian Plain) Tér és Társadalom 7. évf. 1993/3-4. 67-76. p.

- a második lépésben pedig a három erỗforrás nagysága és minôsége alapján a települések pontértéket kaptak.

A pontozás az alábbi kritériumok alapján történt:

a) az adható maximális pontszám azt fejezi ki, hogy az illetỗ erôforrás kategóriáján belül milyen erốs terület-, illetve településfejlesztổ hatást váltott ki az 1950-1980 közötti idôszakban (népességkoncentráció és beruházás);

b) az egyes erôforrások alapján kapott 1-3 pontszámmal az illetố erốforrás terület- és településfejlesztố hatását próbáltuk visszaadni;

c) az egyes erôfforrások alapján adott pontokat nem aggregáltuk, hanem ezek elốfordulása és ,,súlya”, szerkezete alapján tettünk kísérletet típusterületek lehatárolására.

A fenti módszer alapján kaptuk az 1 . ábrát.

E helyt eltekintek a módszer további ismertetésétôl; nemcsak azért, mert örök ellenzổje voltam e módszernek, hanem azért is, mert idejétmúlt. Mégis, kérem, vessünk egy pillantást az ominózus ábrára és hasonlítsuk össze a földhasznosítási szerkezet átalakulását bemutató, a hivatalos statisztika alapján nagy múgonddal elkészített térképpel (1. Magyarország Nemzeti Atlasza 203. oldal, A térkép).

A természeti erôforrások, a társadalmi tér és a földhasználat szerkezete közötti összefüggés már-már evidensnek tũnô területi összefüggéseket láttat. Az Alföldre vonatkoztatva az alábbi területi típusok tũnnek egyértelmûnek:

I. A természeti adottságok elsôsorban megújuló erôforrást jelentenek, ezért a terület-és településfejlódés tartós alapját adják, s így a földhasználati szerkezet lassan módosul.

Dél-Tiszántúl név (I. 1. típusok) alatt foglalható össze az a terület, amelynek központjai Békéscsaba-Gyula, Orosháza, Csongrád-Szentes-Hódmezõvásárhely-Makó és Szeged. E térségben a földgáz és kôolaj, a felszín alatti és felszín feletti vízkészlet, a talajok termốképessége olyan erőforrás, amely az eddiginél nagyobb lokális fejlesztést indukálhat, ha az erôforrások helyi felhasználásának lehetôségei bôvvülnek. A földhasznosítási szerkezet fenntartása, a szántó $70 \%$ feletti aránya mellett szól a nagy helyi élelmiszeripari kapacitás, a fejlett helyi városi piacok és a külpiaci kapcsolatok. Ugyanakkor célszerú lenne a folyók - Körösök, Maros, Tisza - menti ,zöld folyosók”" szélesítése, amely a városi lakosság számára bővíthetné a hétvégi pihenés lehetôségeit, esetenként a falusi turizmus megjelenését, illetve továbbfejlôdését eredményezné. Egészében véve a térhasználat erôsödésével lehet számolni, ami a társadalmi funkciók mind racionálisabb térbeli elhelyezését követeli meg, s ezzel összefüggésben az infrastruktúra gyors ütemũ kiépítését.

A Hajdúság (I. 2. típusok) Debrecennel és a nagykunsági városok közül Karcaggal és Püspökladánnyal olyan fejlesztési sáv, amelynek erôforrásadottságai jelentôsek. A földgáz, a termálvíz, a felszín alatti és feletti vízkészlet alapján itt a terület- és településfejlődés feltételei kedvezôek. Ebbe a fejlődési folyosóba sorolható valójában a nagykunsági várossor Szolnoktól Debrecenig. E települések energiaellátottsága (helyi vagy szállított), 


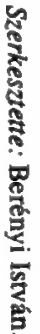

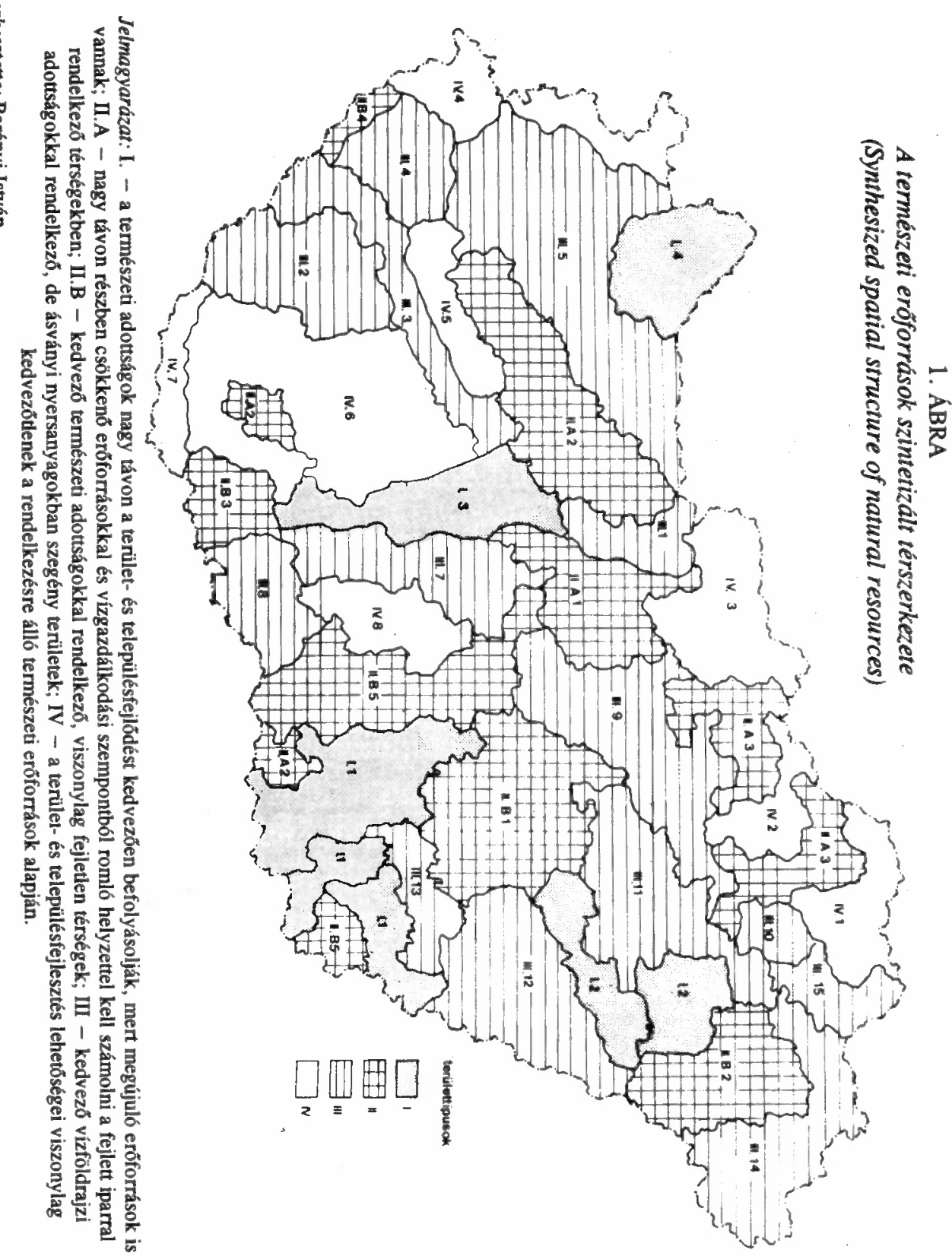


Berényi István : Az Alföld földhasznosítási szerkezetének várható átalakulása

(Expected Situation of he Structure of Land Use of the Great Hungarian Plain)

Tér és Társadalom 7. évf. 1993/3-4. 67-76. p.

vízföldrajzi helyzete, agrárterületének termôképessége, általános forgalmi helyzete olyan erőforrás, amely ma kevéssé kihasznált. Ennek ellenére a földhasználat intenzív fejlesztésének lehetôsége korlátozottabb, mint a Dél-Tiszántúlon, mivel a termốterület 20-30\%át nagy kiterjedésũ, gyenge hozamú és részben természetvédelem alatt álló gyepek teszik ki. Ez az extenzív jellegü földhasználat a kisüzemek megerôsödésének sem kedvez, az intenzív kultúrák müködésének pedig - ami a kisüzemek gazdálkodását biztonságosabbá tehetné - nincs tradíciója. Ugyanakkor esélyt látok az extenzív állattartás ,,klasszikus" formáinak feléledésére, amennyiben az élőállat értékesítés kedvezổbbé válik.

Valószínúsíthetô, hogy a városok környékén kiszélesedik a kertgazdálkodás. Súlyos gond az erdö rendkívül alacsony aránya, miközben növelésének, telepítésének feltételei is rosszabbak, mint a Dél-Tiszántúlon.

A Közép-Duna mente (I. 3. típus), Dunaújváros-Dunaföldvár-Paks és Szekszárd a Mezőfölddel szintén olyan térség, amely bár a természeti adottságokat tekintve szerényebb, mint az elôző két térség, mégis jelentôs, mert olyan jellegũ területekkel érintkezik (Budapest, közép-dunántúli iparvidék, Balaton), amelyek gazdasági húzóereje nagy távon érvényre juthat.

A kedvezô forgalmi helyzet és a felszín alatti és feletti vízkészletek bốsége a jövố városfejlôdése szempontjából döntổ lehet.

A területhasználat a hidak révén a Duna-Tisza közével is funkcionális kapcsolatban van (pl. erdốgazdálkodás, halászat stb.), de az Alföld fejlôdése végeredményben nem sok hatással lehet a terület földhasználatának változására. Erốteljesebb urbanizációt feltételezve a mezôgazdasági terület csökkenésével lehet számolni, és csak bizonyos területeken (a Mezőföld, Szekszárd környéke) képzelhetổ el a földhasznosítási szerkezet stabilizálódása.

II. Hosszú távon részben csökkenố erôforrásokkal és vízgazdálkodási szempontból romló helyzettel kell számolni a fejlett iparral rendelkezô térségek alföldi peremein.

Az Északi-középhegység övezetében a Zagyva-völgy és a Sajó-völgy fejlesztési sávjainak van esélye a növekedésre. A fejlesztés azonban az Alföldre nyíló völgytorkolatban - például Hatvan esetében - valószinũsíthetố, ahol eltérô gazdasági adottságú területek különbözõ erõforrásainak felhasználására van lehetôség (II. A. 3. típus).

Nem elképzelhetetlen, hogy a Gödöllô-Hatvan-Gyöngyös-Mezókövesd-Szerencs tengelyhez kapcsolódnak az északi iparvidékek, ami e zóna földhasználatának átalakulásával járhat. Ez esetben az élelmiszeriparra építhetố agrártermelés, a helyi piachoz és idegenforgalomhoz kapcsolódó szôlố- és gyümölcstermelés erôsödhet meg. 
Berényi István : Az Alföld földhasznositási szerkezetének várható átalakulása

(Expected Situation of he Structure of Land Use of the Great Hungarian Plain)

Tér és Társadalom 7. évf. 1993/3-4. 67-76. p.

II. B. Kedvezó természeti adottságokkal rendelkezô, viszonylag fejletlen térségek (II. B. típusok)

A Közép-Tisza-vidék Szolnokkal fejletlenebb (II. B. 1. típus), mint az az adottságokból következnék (földgáz, termálvíz, felszín alatti és feletti vízkészlet stb.). Különösen a Szolnok - Törökszentmiklós - Tiszaföldvár háromszögnek volna esélye a dinamikusabb fejlõdésre.

A földhasznosítási szerkezet rendkívül kedvezốtlen, mert a nagyüzemi gazdálkodással a szántóföldi növénytermelés a mezốgazdasági terület több mint $80 \%$-át foglalja el. Feltételezhetố, hogy a szántó területe $15-20 \%$-kal csökken az ezredfordulóig.

Hasonló, de kevésbé hasznosuló természeti potenciállal rendelkezik NyíregyházaNagykálló-Nyírbátor környéke (II. B. 2. típus). A szomszédos országok energiaforrásai, a hulladékfa mennyisége és az agrártermelés olyan erôforrások, amelyeknek elképzelhetõ nagyobb helyi felhasználása, különösen az erôs munkaerõkínálat miatt.

A földhasználati szerkezet kedvezőbb, mint a Közép-Tisza-vidéken, mert a változatosabb talajadottságok, talajvíz-viszonyok differenciáltabb hasznosítást tesznek lehetỗvé. Ez kedvez a kisüzemek megerõsödésének is. Ugyanakkor azzal a veszéllyel jár, hogy a kezdeti években elôtérbe kerül a termelési ,, autarchiára", biztonságra törekvés.

Az Alsó-Duna-völgye (II. B. 3. típus) - Baja és Mohács - fejlesztési adottságai is kedvezõbbek, mint e városok, illetve térségek általános gazdasági-társadalmi fejlettsége. A vízkészlet és az agrártermelés színvonala nagyobb és színvonalasabb feldolgozóipart feltételez. Az erdõ és a mezõgazdasági terület ésszerũ hasznositása tartós térségfejlesztési potenciál. Egészében a földhasznosítási szerkezet mai arányai kedvezôek.

A Duna-Tisza köze keleti pereme (II. B. 5. típus) - Kecskemét, Kiskunfélegyháza, Kiskunmajsa - lehetôségei a földgáz- és részben a kõolajelőfordulással, valamint a kertészeti kultúrák erốsödésével nốttek meg. E településsor azonban nem alkot ,,egységes" gazdasági-társadalmi térszerkezetet, mert Kecskemét a fỗváros, Kiskunmajsa Szeged vonzásába esik. A természeti erôforrások tekintetében viszont közel azonos helyzetben vannak.

A földhasznosítási szerkezet viszonylag változatos, csak dél felé nô fokozatosan a szántó aránya. A Cegléd-Nagykổrös-Kecskemét város-hármas funkcionálisan átfoghatja a központi terület agrártermelését.

III. A harmadik típusba azokat a település-csoportokat, térségeket soroltuk, amelyek energetikai szempontból erôsen ellátatlanok, számottevố ásványkincsük nincs, vízföldrajzi adottságaik viszont nem kedvezôtlenek, az agrártermelés feltételei pedig átlagosak vagy annál valamelyest gyengébbek.

A Solti- és a Kalocsai-síkság (III. 7. típus), valamint a Bácska kedvezõ agrártermelési potenciállal, vízföldrajzi adottsággal, de gyenge energetikai lehetôségekkel rendelkezik. Különösen kedvezôtlen a Kunszentmiklós-Szabadszállás környéki kistérség, ahol az 
Berényi István : Az Alföld földhasznositási szerkezetének várható átalakulása

(Expected Situation of he Structure of Land Use of the Great Hungarian Plain)

Tér és Társadalom 7. évf. 1993/3-4. 67-76. p.

agrártermelés feltételei is gyengébbek, mint a Kalocsai-síkságon vagy a Bácskában. A terület földhasználati szempontból erôsen szántóföldi jellegũ, de csak látszólag egyoldalú a hasznosítása, mert a Duna mellett sorakozó községek sokkal jobb termelési helyzetben vannak (öntözés), mint a keleti perem községei. Elképzelhetô,, hogy ez utóbbiakban a földhasználat tovább tolódik extenzív irányba.

A Jászság és Heves déli része (III. 9. típus) átlag feletti agrártermelési adottságokkal rendelkezik. Energiában és ásványi anyagokban szegény, míg vízföldrajzi helyzete a települések fejlesztése szempontjából nem kedvezôtlen. Ugyanakkor az ország gazdasági-társadalmi térszerkezetében viszonylag kedvezố forgalmi helyzetben van. Ezért összességében a települések egy részének fejlesztési lehetôsége jó - például Heves, Jászberény -, de még Jászapáti, Jászárokszállás, Nagykáta és az említett Hatvan lehetôségei is jobbak, mint a társadalmi hasznosítás jelen szintje.

A szántó kiugróan magas aránya, különösen a Jászságban, egyértelmũen hasznos. E térségben is számolni lehet a szántó $15-20 \%$-os csökkenésével, fốként a szikesedésre hajló, gyenge termốképességũ területeken.

Ezzel szemben az Alföld kedvezőtlen fejlesztési lehetőségekkel rendelkezô területtípusai közé sorolható Tiszafüred és tágabb környéke (III. 11. típus), valójában a KözépTisza-vidék. E térségnek még agrárföldrajzi adottságai is átlag alattiak amellett, hogy egyéb természeti erôforrásokkal úgyszólván teljesen ellátatlan. Nehezen feltételezhetố, hogy Tiszafüred mérsékelt fejlesztése esetén a többi településnek ennél nagyobb esélye lenne a termelôerớk koncentrálására. Ebbő̉l adódik, hogy a földhasználat extenziv irányú eltolódásával lehet számolni. Különösen kedvezổ lenne, ha a Tisza sávjában jelentốsebb erdổtelepítésre kerülhetne sor.

A Körös- és Berettyó-vidék (III. 12. és 13. típusok) - Berettyóújfalu, Derecske, Dévaványa - helyzete hasonló, sốt némileg még rosszabb is. Különösen kedvezôttlen, hogy a terület perifériális jellegén alig lehet változtatni. Agrárpotenciálja is átlag alatti, így a helyi erôforrások felhasználásán alapuló gazdasági tevékenység megvalósítására is kevés a remény. Hasonló terület Békés megye északi pereme.

A földhasználati szerkezet valamivel kedvezổbb, mint a Közép-Tisza-vidéken és a terület „kiszáradása” sem érte el az ottani mértéket, ezért agrár-ökológiai egyensúlyának helyreállítására nagyobb az esély.

E tekintetben még kedvezốbb helyzetben van Szatmár-Bereg (III. 14. típus), ahol a speciálkultúrák jelenléte, az alföldi átlagnál nagyobb erdôsültség jobb feltételeket nyújt a terület- és településfejlesztés számára. A felszíni vízkapacitás szempontjából is kedvezôbb terület, mint a Körös-vidék. A falusi turizmus fejlesztésének különösen jók a lehetôségei.

Az agrártáj megỗizte jellegét a nagyüzemi gazdálkodás idốszakában is, ezért inkább a földhasználati szerkezet fenntartására, megerôsítésére kellene törekedni. 
Berényi István : Az Alföld földhasznositási szerkezetének várható átalakulása

(Expected Situation of he Structure of Land Use of the Great Hungarian Plain)

Tér és Társadalom 7. évf. 1993/3-4. 67-76. p.

IV. A kedvezôtlen természeti adottságok, az eröforrások hiánya az Alföldnek csak kisebb kiterjedésũ területein jelennek meg mint fejlesztést akadályozó tényezôk.

Az említett pontozás alapján a Duna-Tisza közötti hátság minõsült a legkedvezốtlenebb területnek, ami szintén mutatja a pontozásos tipizálás veszélyét, hiszen e vidék szõlốterületei és sajátos szövetkezeti gazdálkodása révén a ,,szocialista mezõgazdaság”" egyik siker-területe volt. A sajátos földhasznosítási szerkezet, az üzemi és településstruktúra elvileg a legkedvezőbb pozícióban várja a piacgazdaságba való menetelést.

$\mathrm{Az}$ ásványi nyersanyagok előfordulása, a talajminőség és a vízkészletek alapján is jelentốs altérségek vannak az Alföldön, s e területi különbségek közvetve vagy közvetlenül, de nagyon eltérõ módon befolyásolják az agrártermelést és vele összefüggésben a földhasználat szerkezetét. Ez esetben a természeti tértagolódás felôl próbáltuk felvázolni a földhasználat átalakulásának várható irányait. A természeti tér-gazdaság-társadalom hármas struktúrájának összefüggése azonban történeti változásában értelmezhetố igazán, mivel az egyes struktúráknak sajátos önmozgása, eltérố idốbelisége van, miközben magukon viselik, visszatükrözik a többi szerkezetben bekövetkezett változásokat. A természeti térhasználat, s így a földhasználat magában hordozza az ott élô ember gazdasági-társadalmi viszonyait.

Az Alföld földhasználatának változása tehát szükségszerũ folyamat, de nem rajtunk kívülálló objektivitás, ezért az ember érdekében történõ befolyásolása racionális társadalmi cselekvés.

\section{Irodalom}

Berényi I. (1993) A Jászság földhasználatának változásai. In: Jászsági Évkönyv. (Szerk.: Pethổ L.) Jászberẻny. $89-98$. o.

Enyedi Gy. (1987) Tér és Társadalom. - Janus II., 1. Pécs, 114. o.

Enyedi Gy.-né - Kovács Cs. (1989) A termelés szerkezete és színvonala a mezõgazdasági nagyüzemekben. In: Magyarország Nemzeti Atlasza (Szerk.: Pécs M.) Budapest, 383-384. o.

Henrichsmeyer, W. (1994) Agrarstrukturelle Veränderungen. In: Nachrichten, 1. Akademie für Raumforschung und Landesplanung, Hannover. 7-11.0.

Raumordungsbericht, 1993. Bundesministerium für Raumordung, Bauwesen und Stădtebau. Bonn, 233 o. 


\section{EXPECTED SITUATION OF HE STRUCTURE OF LAND USE OF THE GREAT HUNGARIAN PLAIN}

\section{ISTVÁN BERÉNYI}

Hungarian agriculture had a successful period between 1965-1985 from the point of view of mere production, the foundation of which were the lucky combination of the big farms and private enterprises (homesteads), and also the mass production background which was provided by the COMECON-market. The crisis signs of the agrarian production built on the complicated system of state subsidies appeared in the beginning of the 1980s. By that time the machinery of the big farms had lost its value. At the same time the prices of the industrial products necessary for the maintenance of the level of production (fertiliser, pesticides, machines etc.) had gone up. The market became narrower, because the importing socialist countries lost their solvency one after the other. In $1985,40 \%$ of the big farms were not able to produce the criteria of the reproduction.

After the change of 1989 he European market widened theoretically, but not to the extent that could mean a way out of the over-production crisis. In fact, the appearance of Hungarian and Eastern European agrarian products on the Western European market brought focus on the inner contradictions of the EC agrarian policy. According to Henrichsmeyer, an eventual agrarian reform of the EC would result in a 30-40\% decline in the collection prices, another $15 \%$ decrease in the agricultural land and the growth of the extensive features of production. There is a very slight chance that the Community can take all these up in these years.

Thus the crisis Hungarian agriculture were brought about by the continuous and unfavourable changes of inner and outer conditions. A quick change of paradigm cannot be expected, since the new European frameworks in which the obviously overgrown home agrarian production has to find its place rare still unknown.

The gradual formation of the common European market forces the reconstruction of the structure of agricultural production, and also the reformation of land use structure. From the point of view of the change of the land use structure, it is evident that those parts of the country will be intensively or less intensively tilled that have certain comparative advantages (fertility, transportation-market location, social-settlement background etc.) in the home or European regional system.

In our study we defined the regions of the Great Plain with different productive potentials that, in our opinion, have special agrarian potentials from the aspects of regional planning and settlement development, and the ownership and productive relations, the whole vertical system of production has to be transformed according to 
this. This has to be based mainly on the local natural-economic-social resources, and the whole of the stimulation should be built on it.

According to the above-mentioned requirements we defined the following spatial types:

I. The natural endowments and the economic-social background of the production forces the maintenance of the agrarian structure, the opportunity for change is little and slow.

II. Though the natural conditions of the production are favourable, some elements of the present economic-social background find difficulty in adjusting themselves to the new-type agrarian production, thus the directions of the production must be found.

III. In these type areas the crisis of the agrarian production is the consequence of the big farm system, amounting to monoculture, strengthening and conserving the agrarian features of the social structure and resulting in the functional decline in the importance of the agrarian towns. In these areas the decrease of the production in inevitable, also the reformation of the structure and the construction of the vertical system of production, procession and marketing.

IV. The Great Plain has got special agrarian regions, e.g. areas of intensive wine and fruit production, or, on the other hand, areas with extremely extensive culture (Hortobágy), that require special regional developmental conception.

This brief summery of the regional types is meant to support the view that the development of the Great Plain cannot be considered as a homogeneous region from the point of view of agrarian production, so a regionally "sensitive" developmental conception has to be worked out, which is a part of a long term regional developmental notion. 